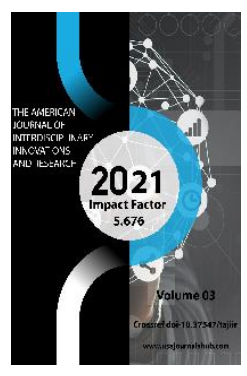

\title{
Specific Analysis And Evaluation Competitor On The Ability Of Tourism In Uzbekistan
}

\author{
Usmanova Dilafruz Karshiyevna \\ Ph.D, Assistant Professor Of Digital Economics,.SamSU, Uzbekistan
}

\section{ABSTRACT}

The competitiveness of national tourism is one of the components of the country's competitiveness. The competitiveness of national tourism is determined by the tourism potential of ten nations, unique culture, traditions, history, as well as the country's image, effective government policy aimed at developing national tourism as a strategic industry, investments and innovations in this industry. In the article, the author proposes a methodology for assessing the competitiveness of the nation on the basis of the UNWTO recommendations and conducted a SWOT analysis of national tourism in the republic, on the basis of which proposals were developed to increase the country's competitiveness.

\section{KEYWORDS}

Competitiveness, destination, indicators, pandemic, social inclusion, digitalization, UNWTO.

\section{INTRODUCTION}

One of the components of the country's competitiveness is the competitiveness of tourism. The competitiveness of tourism is considered by researchers depending on their subjective reasoning about competitiveness and the significance of its individual indicators for the sustainable development of destinations. The existing approaches to the 
interpretation of the economic essence of competitiveness differ significantly from each other. The main differences of the authors are in the interpretation of the reasons for the emergence of competitiveness, its target orientation, quality characteristics, as well as the relationship with a similar property of products and industries (national economy). Competitiveness is its complex property, different from the potential, competitiveness of the enterprise, industry, country as a whole, and the effectiveness of its activities.

The proposed conceptual approaches to determining the competitiveness of tourism are mainly based on the ideas of the "competitive diamond" by $M$. Porter ${ }^{1}$. The most comprehensive and insightful of them is the Ritchie and Crouch model, ${ }^{2}$ in which the competitiveness of a destination is represented by the following main factors: main resources and attractors; - supporting factors and resources; - strategic planning of the development of the destination; - the role of the regulatory body in promoting the main resources; - situational conditions (political situation, geographical location, etc.). Based on many years of research, it was concluded that the most competitive destination is able to most effectively ensure the sustainable wellbeing of its residents. ${ }^{3}$
In the modern conditions of overcoming the consequences of the pandemic, when the priority task of the state is to restore national tourism as soon as possible and consistently increase the competitiveness of the industry, based on the transition of tourism from the traditional to the investment and innovation model of development. This approach corresponds to the Concept of Tourism development in the Republic of Uzbekistan in 2019-2025 $5^{4}$ The concept of development of the tourism sector of the Republic of Uzbekistan in 2019-2025 is aimed at achieving an increase in the effectiveness of the ongoing reforms to create favorable economic conditions and prerequisites, developing priority goals and objectives for the accelerated development of the tourism industry, increasing its role and contribution to the economy, diversifying and improving the quality of services, as well as improving the tourist infrastructure.

\footnotetext{
${ }^{3}$ Sevara Babanazarova (2020) “About ensuring a fair approach to the effective organization of the professors and teachers work.", Middle European Scientific Bulletin, 5, pp. 88-91. doi: 10.47494/mesb.2020.5.65.

${ }^{4}$ Decree of the President of the Republic of Uzbekistan "On additional measures for the accelerated development of tourism in the Republic of Uzbekistan" dated January 5, 2019 No. DP-5611
} 
The American Journal of Interdisciplinary Innovations and Research (ISSN-2642-7478)

Published: May 31, 2021 | Pages: 124-134

\begin{tabular}{|c|c|}
\hline Regulatory act & quantity \\
\hline \multicolumn{2}{|l|}{ Decisions of the Head of State } \\
\hline Decrees of the President of the Republic of Uzbekistan & 11 \\
\hline Presidential Decrees & 13 \\
\hline Orders of the President of the Republic of Uzbekistan & 1 \\
\hline \multicolumn{2}{|l|}{ Government decisions } \\
\hline Appointments of the Cabinet of Ministers of the Republic of Uzbekistan & 21 \\
\hline Orders of the Cabinet of Ministers of the Republic of Uzbekistan & 8 \\
\hline \multicolumn{2}{|l|}{ Other documents } \\
\hline Joint decision & 1 \\
\hline
\end{tabular}

The adoption of this concept was due to positive developments in the development of national tourism, increasing its competitiveness and the government's desire to ensure sustainable tourism growth. The competitiveness of national tourism was characterized by the following comparative and absolute advantages. Uzbekistan has a huge tourist and recreational potential, which includes 7.4 thousand cultural heritage sites, 209 of them are included in the list of UNESCO World Heritage Sites as part of the four citiesmuseums "Ichan Kala in Khiva", "The Historical Center of Bukhara", "The Historical Center of Shakhrisabz" and "The City of Samarkand"'5.

\footnotetext{
${ }^{5}$ Sevara Babanazarova (2020) “About ensuring a fair approach to the effective organization of the professors and teachers work.", Middle European
}

Scientific Bulletin, 5, pp. 88-91. doi: 10.47494/mesb.2020.5.65. 
SWOT ANALYSIS OF THE COMPETITIVENESS OF NATIONAL TOURISM IN UZBEKISTAN IN THE CONTEXT OF OVERCOMING THE CONSEQUENCES OF THE PANDEMIC *

\begin{tabular}{|c|c|}
\hline Strengths & Weaknesses \\
\hline $\begin{array}{l}\text { Excellent, undisturbed natural resources, historical } \\
\text { cities and UNESCO World Heritage sites in all } \\
\text { countries have a low population density, which } \\
\text { makes the republic a safe tourist destination. The } \\
\text { diversity and uniqueness of Uzbek culture, ethnic } \\
\text { groups and religions, and the culinary experience. }\end{array}$ & $\begin{array}{l}\text { High cost and weak air links Insufficient transport } \\
\text { infrastructure, roadside } \\
\text { facilities along tourist routes, tourist services } \\
\text { and signs on tourist sites. }\end{array}$ \\
\hline $\begin{array}{l}\text { The quality of accommodation and accommodation, } \\
\text { and other }\end{array}$ & $\begin{array}{l}\text { Burdensome border crossing procedures and } \\
\text { visa procedures. }\end{array}$ \\
\hline $\begin{array}{l}\text { tourist facilities in the capitals. } \\
\text { Internationally recognized brand: Silk Road }\end{array}$ & $\begin{array}{l}\text { Limited capacity for socially responsible practices } \\
\text { and the preservation of tourism }\end{array}$ \\
\hline The local population is very hospitable to & assets. \\
\hline tourists. & $\begin{array}{c}\text { Limited development of products and tourism } \\
\text { experiences }\end{array}$ \\
\hline $\begin{array}{l}\text { Political goodwill and state support for tourism } \\
\qquad \text { development }\end{array}$ & that appeal to the most important market segments. \\
\hline & Language barriers and a shortage of skilled \\
\hline & workers, destination managers and tour guides. \\
\hline Opportunities & Threats \\
\hline
\end{tabular}


The American Journal of Interdisciplinary Innovations and Research (ISSN-2642-7478)

Published: May 31, 2021 | Pages: 124-134

Doi: https://doi.org/10.37547/tajiir/Volume03Issue05-22

Growing international interest and visibility of the Silk Road

\section{Continued expansion of international tourism,}

especially in the fast-growing Asian markets, and travelers ' search for new experiences and untapped

$$
\text { destinations. }
$$

\section{Major regional infrastructure projects}

being developed in the region.

The ongoing development of information technology.

Tourism as an industry that can support economic recovery after the pandemic.

Donor support for eligible tourism projects
Growing international health risks and geopolitical conflicts.

Climate change, including global

warming and environmental degradation.

Security issues and political

instability in neighboring countries

Economic decline in the main markets of origin of tourists.

Natural and man-made disasters.
According to UNWTO, from January to August alone, the drop in export revenue from international tourism amounted to $\$ 730$ billion compared to the same period in 2019. This is more than 8 times higher than the losses incurred as a result of the global economic and financial crisis of 2008-2009. Then, due to the downturn in the economy, rising fuel prices and falling demand for tickets and package tours, dozens of air carriers and tour operators around the world left the market.

The SWOT analysis of competitiveness will allow us to develop a concept for the

\footnotetext{
${ }^{6}$ Ortikniyozovich, F. U. (2020). Theme: Forecasts And Results Of The Negative Impact Of The Covid19 (Coronavirus) Pandemic On The World Economy And The Economy Of Uzbekistan. The American
}

development of national tourism in the postcrisis period. Moreover, coordination and cooperation with global regulators in the field of tourism is important here, a separate destination, the state can strengthen its competitive advantages through the development of domestic tourism, but inbound tourism is not possible without coordinated actions, joint projects for further development. The "One Planet" concept for the sustainable recovery of the tourism sector is based on ${ }^{6}$. The concept calls for a responsible recovery of the tourism sector after the crisis caused by the COVID-19 pandemic. A recovery

Journal of Interdisciplinary Innovations and Research, 2(08), 108-116. 
based on the principles of sustainability and focused on "building better than it was" can serve as a foundation for improving the resilience of the tourism sector?.

The competitiveness of a region or country specializing in tourism is the ability to increase the influx of tourists, increase tourist spending by increasing the wellbeing of the residents of the destination while preserving the natural capital for future generations.

There are many factors that affect the competitiveness of a country specializing in tourism. The integrated competitiveness index in the global ranking of destination countries is formed on the basis of 90 indicators grouped into 14 complex indicators in four sub-indices.

In the model of competitiveness of a tourist destination

Crouch and Ritchie present 36 factors of competitiveness, the most important of which are: 1) geography and climate; 2) culture and history; 3) accessibility; 4) tourist structure; 5) security; 6) cost; 7) market connections; 8) infrastructure. Dwyer and Kim based on these and other factors proposed an indicator of the competitiveness of the destination. ${ }^{8}$

A huge number of factors and indicators of competitiveness are associated with the specifics of the tourist product. The tourist product of the destination region, in

7 https://webunwto.s3.eu-west-1.amazonaws.com/s3fs-public/202005/UNWTO-Global-Guidelines-to-Restart-Tourism.pdf ,

https://www.unwto.org/news/covid-19-international-tourist-numbers-couldfall-60-80-in-2020, https://www.unwto.org/covid-19-travel-restrictions contrast to the goods and services produced by firms, is complex. It consists of the services consumed by the tourist, which are produced by a group of enterprises: hotels, restaurants and cafes, transport, tour bureaus, entertainment industry. In addition to paid services, tourists consume free goods (climate, landscapes, air) and public goods produced by municipal enterprises and organizations: safety, cleanliness, tourist information. Tourists evaluate all the impressions of the trip according to the parameters of cost and quality, accessibility and safety, comfort and usefulness, and the uniqueness of the experience.Accordingly, the problem of the country's competitiveness in the tourism market depends both on the activities of the tourism industry enterprises and on the targeted impact of state and regional government bodies on the change of important factors.

The development of the region's competitiveness is impossible without effective benchmarking - conducting qualitative and quantitative comparisons with similar destinations-competitors in the international market. The basis of benchmarking should be a comprehensive analysis of the tourism potential that the region has. The set of indicators of the competitiveness of the region specializing in tourism presented in the next paragraph is developed by the author on the basis of the adaptation of the indicators of the

\footnotetext{
${ }^{8}$ Ritchie J.R.B., Crouch G.I. The Competitive Destination: A Sustainable Tourism Perspective. Wallingford,

Oxon, GBR, CABIPublishing, 2005, 290 p.
} 
global tourism competitiveness rating to the Global Recommendations for the Resumption of Tourism of the UNWTO, published on May 28, 2020 by the Global Crisis Committee in the Field of Tourism.

The tourism and Travel Competitiveness Index represents the national assessment of the competitiveness of the tourism industry and is a measure of the influence of factors and measures taken by the government to improve the attractiveness of the country in the field of tourism. It should be noted that in the WEF report for 2015, the conceptual approach to the definition of the constituent subindexes is improved and more clearly reflects the previously developed models of Crouch and Ritchie. Although there is some criticism of this rating by scientists and practitioners, it has recently been used frequently in empirical research, as it provides a unique opportunity to conduct comparative and factor analysis for regular comparison and to find new approaches to make improvements.

One of the possible variants of the model for assessing the significance of competitiveness factors in the current realities of the global tourism market is shown in Figure 1. 


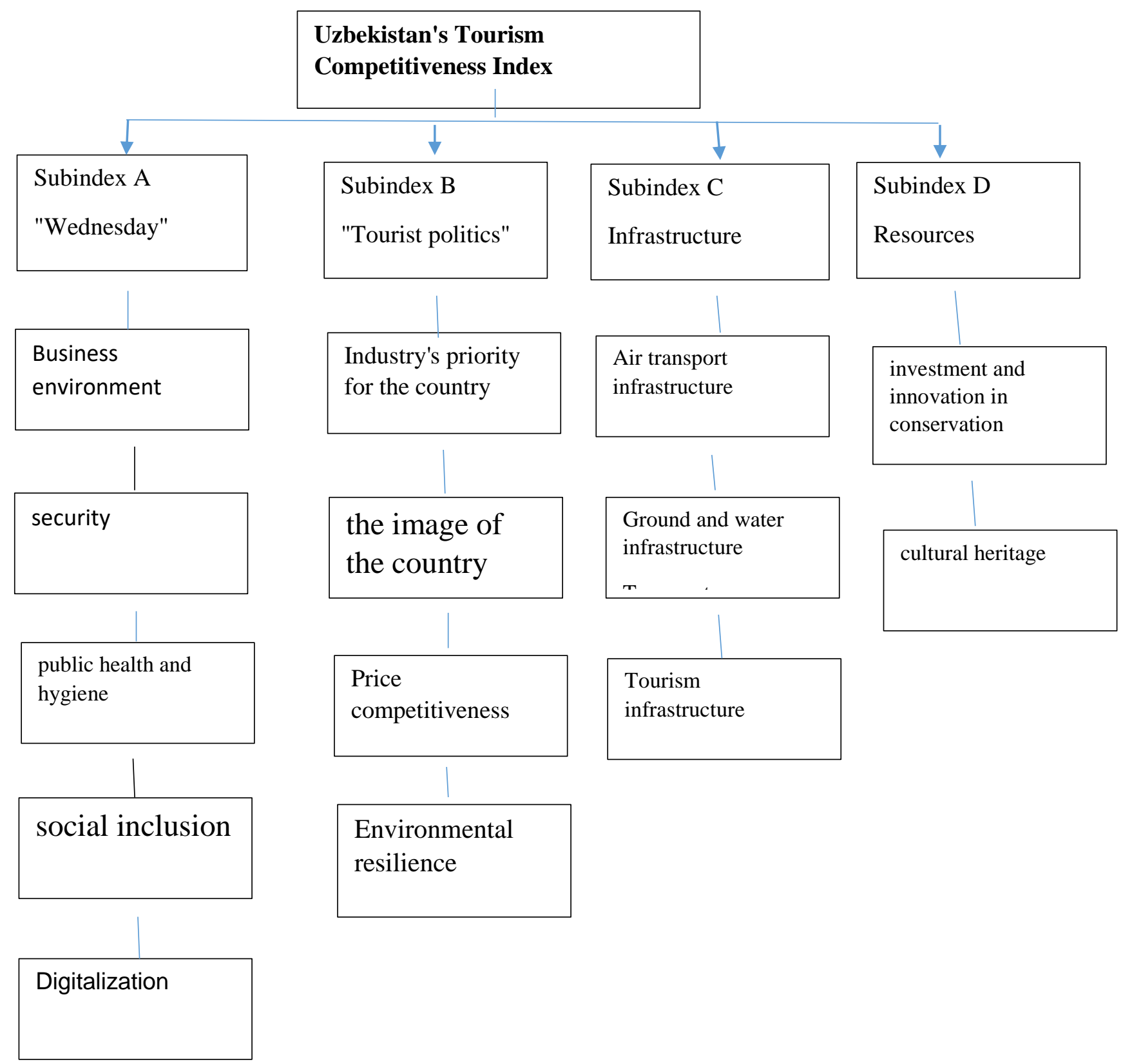

Figure 1. Model of the tourism competitiveness index

This model is based on the dynamics of the number of international arrivals. The proposed model is based on the development of the WEF on the Tourism and Travel Competitiveness Index. 14 indicators of the competitiveness of destinations were used as explanatory factors: 
1) K1i-business environment;

2) K2i-Security;

3) K3i-Public Health and Hygiene;

4) K4i-Social Inclusion;

5) K5i-digitalization;

6) K6i - priority of the industry for the country;

7) K7i-image of the country;

8) K8i-price competitiveness;

9) Kgi-Environmental sustainability;

10) K10i-Air transport infrastructure;

11) K11i-Land and water transport infrastructure;

12) K12i-infrastructure of tourist services;

13) K13i-Investment and innovation in biodiversity conservation;

14) K14i-cultural heritage.

We recommend adjusting individual competitiveness factors.

Общественное здравоохранение и гигиена

The COVID-19 pandemic has clearly demonstrated the close relationship between tourism and public health. The tourism sector has demonstrated its willingness to make a useful contribution by putting its infrastructure, supply chains and personnel at the service of public health and humanitarian assistance. Building long-term synergies between public health and tourism is an investment in preparedness for future crises and contributes to confidence-building. In particular, the assessment of the competitiveness of national tourism should include:
1. The components of the public health and hygiene parameter should contain epidemiological indicators that affect the tourist flow:

- Linking hygiene to sustainability.

- Restoring trust through communication.

2. Social inclusion:

Providing targeted support to vulnerable groups.

Providing long-term support to small and medium-sized enterprises.

Investment and innovation in tourism

Conservation of biodiversity.

3. Investments in converting value chains into tourism.

- Using funds earmarked for recovery to improve

- Quality of tourism.

\section{Digitalization}

Five priority areas for transforming tourism after the COVID-19 pandemic ${ }^{9}$ :

1. Mitigation of socio-economic impacts (job preservation, confidence and security). To this end, a systemic approach is needed to address problems both at the government level by adopting regulations that correct earlier documents to reflect the impact of the pandemic, and at the local government level through employment promotion programmes by engaging . Office of

\footnotetext{
${ }^{9}$ Источник: предложения разработаны автором на основе доклада ООН «COVID-19 и трансформация туризма»
} 
Employment Promotion, organization of a program to reorient the skills and skills of young people in accordance with the requirements of the labor market, the introduction of innovative employment, a fair system of support for the poor through the management of social journals.

2. Improving competitiveness and sustainability (developing tourism infrastructure and improving the quality of services provided, diversifying products and markets, promoting domestic tourism). ${ }^{10} \quad$ The development and implementation of the Concept of yearround Tourism in Uzbekistan will increase the level of competitiveness of national tourism, open new destinations in the country, and raise the relevance, prestige and profitability of domestic tourism. Of course, all this is possible on the basis of the transition to the innovation and investment model of competitiveness.

3. Digitalization (digitalization of the tourism ecosystem, creation of innovative solutions, investment in digital skills). Promotion of the national brand, information about innovations in the field of entry into the country, quarantine measures, visa support, booking can be improved by creating a national tourism platform that provides services to both tourist organizations and tourists.

4. Greening (promotion of sustainable development, introduction of carbonneutral solutions, development of ecotourism). For greening the economy, it is necessary to use a set of financial and

${ }^{10}$ D.Usmanova. Jour of Adv Research in Dynamical \& Control Systems, Vol. 12, 07-Special Issue, 2020.The Impact of Investment on the EconomicDevelopment of Uzbekistan.DOI: 10.5373/JARDCS/V12SP7/20202317 investment tools - to introduce a stock environmental index, which will allow investors to direct funds to the shares of the most environmentally responsible enterprises. Thus, it is necessary to turn the environmental effect into a factor of business capitalization. The business that is greener and more transparent should cost more than the business of less efficient and more closed enterprises

5. Coordination and partnership for the transformation of the sector and the achievement of the Sustainable Development Goals.The successful transition to a more sustainable and resilient tourism model will largely depend on public-private cooperation and partnership. In order to ensure the effective implementation of recovery plans, it is necessary to strengthen cooperation among key stakeholders throughout the tourism value chain, at the international and destination levels, and to give priority to inclusive and interactive approaches.

\section{REFERENCES}

1. “Ўзбекистон Республикасида туризмни жадал ривожлантиришга оид қўшимча чора-тадбирлари тўғрисида» 5 январ 2019 йил 5611-сонли Президент Фармони

2. “Ўзбекистон Республикасида туризм сохасини янада ривожлантириш чоратадбирлари тўғрисида" 13 август 2019 йил 5781-сонли Президент Фармони

ISSN 1943-023X 2008/ Received: 20 May 2020/Accepted: 18 June 2020 
3. "Ички туризмни жадал ривожлантиришни таъминлаш чоратадбирлари тўғрисида" 7 феврал 2018 йил 3514-сонли Президент Қарори.

4. Барчуков И.С. Методы научных исследований в туризме. М.: Академия, 2008. 224 C.

5. Dwyer L., Forsyth P., Rao P. The price competitiveness of travel and tourism: a comparison of 19 destinations //Tourism Management. 2000. Vol. 21. Iss. 1. P. 9-22

6. Морозов М.А., Бубнова Г.В., Щедловская М.В. Применение математических моделей для оценки конкурентоспособности туристской дестинации Наро-Фоминского муниципального района // Современная конкуренция. 2012. № 6. С. 131-141.

7. Sevara Babanazarova (2020) "About ensuring a fair approach to the effective organization of the professors and teachers work.", Middle European Scientific Bulletin, 5, pp. 88-91. doi: 10.47494/mesb.2020.5.65.

8. Портер М.Ю. Конкурентная стратегия: методы анализа отраслей и конкурентов. М.: Альпина БизнесБукс, 2005. 464 C.

9. Ritchie J.R.B., Crouch G.I. The Competitive Destination: A Sustainable Tourism Perspective. Wallingford,Oxon, GBR, CABI Publishing, 2005, 290 p.

10. Сафарова Н.Н.Анализ национальной конкурентоспособности туризма и путешествий: выводы для стран СНГ. Экономический анализ: теория и практика. 30(2015), 54-64

11. The Travel \& Tourism Competitiveness Report 2019 Travel and Tourism at a Tipping Point. Insight Report. Commetted to improving the state of the world.
12. Ortikniyozovich, F. U. (2020). Theme: Forecasts And Results of The Negative Impact of The Covid-19 (Coronavirus) Pandemic On The World Economy And The Economy of Uzbekistan. The American Journal of Interdisciplinary Innovations and Research, 2(08), 108-116.

13. Dupeyras, A. and N. MacCallum (2013), "Indicators for Measuring Competitiveness in Tourism: A Guidance Document", OECD Tourism Papers, 2013/02, OECD Publishing.

14. Regional Agrotourism CompetenceAssessment: Theoretical Approaches. Jour of Adv Research in Dynamical \& Control Systems, Vol. 12, 07Special Issue, $2020 . \quad$ DOI: 10.5373/JARDCS/V12SP7/20202316ISSN 1943-023X 2000. Received: 20 May 2020/Accepted: 18 June 2020

15. http://dx.doi.org/10.1787/5k47tgq2t923-en

16. https://wwKw.unwto.org/news/covid-19international-tourist-numbers-could-fall60-80-in-2020

17. Концепция «одна планета» в интересах устойчивого восстановления туристского сектора. Доклад UNWTO, 2020 